\title{
Chapter 3 \\ Participatory Planning in a Post-socialist \\ Urban Context: Experience from Five \\ Cities in Central and Eastern Europe
}

\author{
Saša Poljak Istenič and Jani Kozina
}

\begin{abstract}
The aim of the chapter is to assess how post-socialist cities and towns encourage the involvement of their citizens into decision-making outside electoral procedures. It presents an analysis of the structures, mechanisms, and specificities related to participatory planning in five municipalities of Central and Eastern Europe: Prague 9 (Czech Republic), Velenje (Slovenia), Székesfehérvár (Hungary), Blagoevgrad (Bulgaria), and Vaslui (Romania). It is based on the self-assessment of public administrators providing their identification and evaluation of the mechanisms as well as their subjective perception of participatory planning at the strategic and neighborhood level. The results revealed that participatory planning remains a great challenge in a post-socialist urban context. We conclude that it is important to work with both citizens and public officials if we want to enforce participatory planning as an efficient governance model.
\end{abstract}

Keywords Participatory planning $\cdot$ Citizen initiatives $\cdot$ Participatory mechanisms Administrative qualifications $\cdot$ Post-socialist countries

\subsection{Introduction}

In 2009, the Slovenian government launched a website called "I Suggest to the Government" (predlagam.vladi.si) to open up a new communication channel between citizens and the state and among the citizens themselves. Its aim has been:

To achieve greater participation of individuals and civil society in the forming of governmental policies and to strengthen the dialog between civil society and the state. (Vlada 2018)

S. Poljak Istenič $(\varangle)$

Research Centre of the Slovenian Academy of Sciences and Arts, Institute of Slovenian

Ethnology, Ljubljana, Slovenia

e-mail: sasa.poljak@zrc-sazu.si

J. Kozina

Research Centre of the Slovenian Academy of Sciences and Arts, Anton Melik Geographical Institute, Ljubljana, Slovenia

e-mail: jani.kozina@zrc-sazu.si

(C) The Author(s) 2020

J. Nared and D. Bole (eds.), Participatory Research and Planning in Practice,

The Urban Book Series, https://doi.org/10.1007/978-3-030-28014-7_3 
Five years later, the website had 12,891 registered users, who supported 1675 citizens' proposals, which received 1455 responses from the ministries and government services. However, only 25 proposals out of these 1455 - or $1.7 \%$-received a positive response and even fewer proposals were actually implemented (Kajtazović 2014).

The numbers illustrate the main problems with participation. First, the mechanisms that provide a possibility for citizens' engagement are neither sufficient to achieve greater participation nor address all citizens in the same way. Second, decision-makers are not necessarily motivated to accept participation as a method for better governance nor skillful enough to respond in an efficient way. Still, the political and professional public agree that the key global problems can only be solved with the active involvement of citizens or communities (Fakin Bajec and Poljak Istenič 2013). An increasing amount of time, efforts, and resources (Horizon 2020, Interreg programs, etc.) has been thus invested either into developing participatory methods and tools to achieve shared governance, into increasing the competences of public administrations to implement participatory decision-making, or into stimulating the passive, indifferent, disengaged but also marginalized citizens to communicate with the authorities and participate in public policy processes.

Democracy has been one of the crucial domains dealing with participation. The current debates took off in 1962 with the Port Huron Statement, a call (or manifesto) for participatory democracy in which individual citizens could help make decisions that affect their lives (see Hayden 2012). The central feature of participation in this line of studies is that it is political (White 1996; Legacy 2017); however, the scope of the politics cannot be confined only to the institutional politics. It has been broadened by interest groups, social movements, civil society, and activists, leading democratic theory to incorporate the analysis of their heterogeneous and multidirectional participatory practices to explore its dimensions (Carpentier 2011).

Participatory democracy has transformative potential, as it is believed that it can ensure a more egalitarian relationship between the state and society and that it can emancipate and empower citizens for dealing with political institutions, bureaucracy, work, school, family, or other spheres of their daily lives (Pateman 1970). But with a prevalence of the representative democracy, in which participation is limited to a selection of the elite through elections, participatory democracy is still believed to be in need of evolvement-a "political project" of sorts with the aim to "deepen democracy" (Fung and Wright 2001) — and has even been labeled a "political utopia" (Bherer et al. 2016, p. 228).

One of the actions toward "deeper" democracy has been participatory planning, an approach which emphasizes community involvement in the strategic and management processes of planning and makes use of its stakeholders' knowledge, resources, and commitment (McTague and Jakubowski 2013). Generally, the term participation in the planning or development domain is used to denote very diverse actions, from civil debate and communication, consultation and the delegation of activities, to partnerships, communal meetings, and political decentralization (Davidson et al. 2007). The prevailing goal is to reach a consensual decision, although allowing citizens to confront and challenge the project in question might prove as a more efficient plan- 
ning strategy (Legacy 2017). Indeed, the people involved are not always allowed to be active participants; instead, they are often limited to a passive role of data providers or informants, sometimes even manipulated into taking part in order to legitimize a decision (Chouinard and Milley 2018). Participation can thus be twisted into a mere instrument for reinforcing domination and control (Gaventa 2004) and is, in its current forms, failing to neutralize and transform power relations (Purcell 2009). For participation to be more transformative, a shift is needed from a vision of inclusion that conceptualizes the participants as data sources, as "representation," to one that recognizes participants as equals in terms of power, resources, and voice (Chouinard and Milley 2018). Some even advocate participation through radical counterhegemonic mobilization, as participatory models based on consensus often silence a minority, especially less privileged groups (Purcell 2009), or a "democracy without participation" where a regime would satisfy the requirements of political equality in the absence of widespread citizens' engagement (Parvin 2018). Besides the power inequalities, participatory planning is also often criticized as insufficiently addressing institutional inertia as well as the complexity of the geographical scale, temporality, and political context (Legacy 2017).

To overcome these obstacles, the bulk of works, beginning with Arnstein's ladder of citizen participation (1969), have discussed participatory methods, techniques, or models, explaining degrees, typologies, or approaches to this phenomenon and often outlined a toolbox for participatory planning or other actions. A study from 2012 focusing on youth outlining as many as 36 participation models (Creative Commons 2012), while a study from 2016 identified 18 new models developed after 2012, or 54 altogether (Hussey 2017), indicating an accelerated search for new mechanisms to encourage more active citizenship as well as a growing diversity of the forms of citizen participation.

However, the possibility of citizens' engagement cannot be taken as a given, even if the mechanisms are created (Gaventa 2004). To increase the use of participatory processes, it is not important to merely teach the initiators how to include people but also to inform practitioners about participatory methods and techniques (Nared et al. 2015). Some people find it easier, more beneficial, or habitual not to participate. Participation is thus often only nominal (on paper) or, at best, instrumental (not valued in itself but needed to achieve some goal, even forcedly) (White 1996). This is especially characteristic for post-socialist countries with a lack of democratic tradition (Bole et al. 2017; Poljak Istenič 2019). While it is a fact that old and young democracies both face a decline of conventional political participation (voting, contacting government officials, etc.) — and the latter also lack nonconventional (protest) political participation (demonstrations, signing of petitions, etc.)—, younger democracies (i.e., post-socialist countries) lag behind older ones with a substantially lower level of participation (in elections and other political processes including participatory planning) (Teorell et al. 2007). Besides the weak democratic consolidation in ex-socialist countries, the reason may also lie in socialization under socialism, which instilled a set of values in the population that was more concerned with social and economic equality than political freedom (Finkel et al. 2001; Neundorf 2010). The extent of weak participation or even "nonparticipation" (Greenberg 2010) is also positively 
correlated with economic development, which is ordinarily lower in post-socialist countries (Hafner Fink 2012).

To assess how post-socialist cities and towns encourage the involvement of their citizens into decision-making outside electoral procedures, the chapter provides an analysis of the structures, mechanisms, and specificities related to participatory planning in five municipalities from Central and Eastern Europe: the municipal district Prague 9 (Czech Republic-CZ), the Municipality of Velenje (Slovenia-SI), the Municipality of Székesfehérvár (Hungary-HU), the Municipality of Blagoevgrad (Bulgaria-BG), and the Municipality of Vaslui (Romania-RO). It is based on the self-assessment of public administrators from selected municipalities providing their identification and evaluation of the mechanisms as well as their subjective perception of participatory planning at the strategic and neighborhood level. Having in mind the issues with participatory planning outlined above, we address the following research questions: Is participation in the selected municipalities generally a top-down or bottom-up initiative? Which mechanisms are used to allow citizen participation? Do the municipalities specifically address any marginalized groups that are generally excluded from decision-making processes? What is the experience of municipalities with any previous attempts of participatory planning? Are municipal officials sufficiently qualified to implement participation?

\subsection{Research Design}

The sample of the five listed municipalities was selected for their recent aspirations in improving participatory planning mechanisms through active involvement in the project AgriGo4Cities: Urban Agriculture for Changing Cities: Governance Models for Better Institutional Capacities and Social Inclusion (Danube Transnational Program, 2017-2019). In order to assess the municipalities' potentials to employ urban agriculture as a tool for citizen participation and the social inclusion of vulnerable groups, we prepared a questionnaire on the structures, mechanisms, and experience related to participatory planning. Generally, we distinguished between two levels of planning. Strategic planning is a broader category and simply encompasses designing strategic documents for an entire city/municipality (development strategies, action programs, etc.), while neighborhood planning deals with a level of planning greater than household size but smaller than that of a city/municipality (Ministry of Housing, Communities \& Local Development 2014). The main set of questions was taken from our previous analyses of participatory planning when managing urban green spaces (Urban Green Belts project 2017) and transport in metropolitan regions (Sustainable Measures for Achieving Resilient Transportation in Metropolitan Regions project 2016).

Altogether, five questionnaires were sent to the selected municipalities in March 2017. They were filled out by the adequate public administrators and returned in May 2017. The results and conclusions were synthesized in a draft version in June 2017 and, after receiving comments and amendments from the administrators, in a 
final version in July 2017 (see Kozina et al. 2017). In October 2018, the analysis was again discussed with the municipalities' representatives in order to clarify potential conflicting answers and address the missing gaps. This final checkup revealed that some municipalities have included additional tools for citizen participation at the strategic and/or neighborhood level in the course of the AgriGo4Cities project, so we also included these answers into our analysis.

To have a clearer contextual background and a deeper understanding of the structures, mechanisms, and experience related to participatory planning in the selected municipalities, their demographic and socio-economic characteristics were analyzed comparatively with the entire European Union (for details see Kozina et al. 2017). The data used in the analysis are part of the EUROSTAT database. Statistical data at the municipal level are rarely available in multinational statistical databases. The only exception is the change of the number of the total population between census years at the LAU 2 level. The analysis was further elaborated at the regional levels of NUTS 3 and NUTS 2 and shows the broader regional contexts of demographic and socio-economic development. Because all five municipalities are also important administrative, educational, and employment centers in their regions, we believe that the data can be informative and important for local levels as well.

\subsection{The Demographic and Socio-economic Context of the Selected Municipalities}

The analysis of the EUROSTAT's statistics revealed differences and similarities between the selected municipalities. In comparison to the European Union average, Prague exhibits positive demographic and socio-economic trajectories, whereas Vaslui represents its antipode. Velenje, Székesfehérvár, and Blagoevgrad reflect mixed results (Table 3.1).

Table 3.1 Demographic and socio-economic characteristics of the selected municipalities in Central and Eastern Europe

\begin{tabular}{l|l|l|l}
\hline Municipality & Population statistics & $\begin{array}{l}\text { Educational and } \\
\text { economic structure }\end{array}$ & $\begin{array}{l}\text { Social exclusion and } \\
\text { poverty }\end{array}$ \\
\hline Prague (CZ) & Positive trends & Favorable conditions & Low risk \\
\hline Velenje (SI) & Stagnating trends & Average conditions & Low risk \\
\hline $\begin{array}{l}\text { Székesfehérvár } \\
\text { (HU) }\end{array}$ & Stagnating trends & Average conditions & Medium risk \\
\hline Blagoevgrad (BG) & Stagnating trends & Favorable conditions & High risk \\
\hline Vaslui (RO) & $\begin{array}{l}\text { Stagnating to negative } \\
\text { trends }\end{array}$ & $\begin{array}{l}\text { Unfavorable } \\
\text { conditions }\end{array}$ & High risk \\
\hline
\end{tabular}

Source Own elaboration based on the EUROSTAT database 
The analyzed municipalities are diverse in number of inhabitants (LAU 2 level). While Prague stands out as the only large city, a capital city, and a core of the metropolitan area, the other towns are significantly smaller (Table 3.2). Velenje (sixth rank in Slovenia), Székesfehérvár (ninth rank in Hungary), and Blagoevgrad (fifteenth rank in Bulgaria) represent medium-sized towns within their national urban systems. However, they do not represent the most important regional centers but correspond more to third-tier towns. While Székesfehérvár exhibits a central location in the vicinity of Budapest, Velenje and Blagoevgrad classify into the inner periphery. Vaslui (fortieth rank in Romania) represents a small peripheral town. The total population growth shows two models of population development. Prague has had a permanent, but slow population growth in the entire period since 1961. The population growth was based mainly on positive net migration. The population in other municipalities kept growing steadily until 1991 and has remained relatively

Table 3.2 Demographic and socio-economic characteristics of the selected municipalities and their wider regional settings (-below EU average, $\bigcirc$ EU average, + above EU average)

\begin{tabular}{|c|c|c|c|c|c|}
\hline Municipality & Prague $(\mathrm{CZ})^{\mathrm{a}}$ & $\begin{array}{l}\text { Velenje } \\
\text { (SI) }\end{array}$ & $\begin{array}{l}\text { Székesfehérvầ } \\
(\mathrm{HU})\end{array}$ & $\begin{array}{l}\text { r Blagoevgrad } \\
(\mathrm{BG})\end{array}$ & $\begin{array}{l}\text { Vaslui } \\
(\mathrm{RO})\end{array}$ \\
\hline \multicolumn{6}{|c|}{ Population growth by municipalities, Census data from 1961 to 2011 (LAU 2 level) } \\
\hline $\begin{array}{l}\text { Number of } \\
\text { inhabitants in } 1961\end{array}$ & $1,133,000$ & 13,000 & 59,000 & 28,000 & 18,000 \\
\hline $\begin{array}{l}\text { Number of } \\
\text { inhabitants in } 1991\end{array}$ & $1,214,000$ & 33,000 & 108,000 & 68,000 & 74,000 \\
\hline $\begin{array}{l}\text { Number of } \\
\text { inhabitants in } 2011\end{array}$ & $1,233,000$ & 33,000 & 101,000 & 70,000 & 70,000 \\
\hline \multicolumn{6}{|c|}{ Components of population growth-crude rates 2010/2015 (NUTS 3 level) } \\
\hline $\begin{array}{l}\text { Natural change of } \\
\text { population }\end{array}$ & + & + & - & - & - \\
\hline Net migration & + & - & 0 & - & - \\
\hline $\begin{array}{l}\text { Total population } \\
\text { change }\end{array}$ & + & O & - & - & - \\
\hline \multicolumn{6}{|c|}{ Total population aged 25-64 by educational attainment level in 2016 (NUTS 2 level) } \\
\hline $\begin{array}{l}\text { Less than primary, } \\
\text { primary and lower } \\
\text { secondary } \\
\text { education }\end{array}$ & - & - & - & - & + \\
\hline $\begin{array}{l}\text { Upper secondary } \\
\text { and post-secondary } \\
\text { nontertiary } \\
\text { education }\end{array}$ & + & + & + & + & + \\
\hline Tertiary education & + & - & - & + & - \\
\hline
\end{tabular}


Table 3.2 (continued)

\begin{tabular}{|c|c|c|c|c|c|}
\hline Municipality & Prague $(\mathrm{CZ})^{\mathrm{a}}$ & $\begin{array}{l}\text { Velenje } \\
\text { (SI) }\end{array}$ & $\begin{array}{l}\text { Székesfehérvầr } \\
\text { (HU) }\end{array}$ & $\begin{array}{l}\text { r Blagoevgrad } \\
\text { (BG) }\end{array}$ & $\begin{array}{l}\text { Vaslui } \\
\text { (RO) }\end{array}$ \\
\hline $\begin{array}{l}\text { Agriculture, } \\
\text { forestry, and } \\
\text { fishing }\end{array}$ & - & ○ & O & ○ & + \\
\hline $\begin{array}{l}\text { Industry, mining, } \\
\text { and construction }\end{array}$ & - & + & + & O & O \\
\hline Services & + & - & - & O & - \\
\hline \multicolumn{6}{|c|}{ Social exclusion and poverty in 2015 (NUTS 2 level) } \\
\hline $\begin{array}{l}\text { People at risk of } \\
\text { poverty or social } \\
\text { exclusion }\end{array}$ & - & - & ○ & + & + \\
\hline $\begin{array}{l}\text { Severe material } \\
\text { deprivation rate }\end{array}$ & - & - & + & + & + \\
\hline $\begin{array}{l}\text { Deaths under the } \\
\text { age of } 65\end{array}$ & O & ○ & - & - & - \\
\hline \multicolumn{6}{|c|}{ Young people in education and employment in 2016 (NUTS 2 level) } \\
\hline $\begin{array}{l}\text { Young people } \\
\text { (18-24 years) } \\
\text { neither in } \\
\text { employment nor in } \\
\text { education and } \\
\text { training (NEET) }\end{array}$ & - & - & - & - & + \\
\hline $\begin{array}{l}\text { Early leavers } \\
\text { (18-24 years) from } \\
\text { education and } \\
\text { training }\end{array}$ & - & - & O & - & + \\
\hline
\end{tabular}

Source EUROSTAT; for details see Kozina et al. (2017)

${ }^{\mathrm{a}}$ For illustration, Prague district 9, on which the following analysis is based, had 57,000 inhabitants in 2015

stable in the last two decades. However, most of the corresponding wider regions (NUTS 3 level) have experienced a significant drop in the population in recent years.

Educational attainment in wider regions (NUTS 2 level) shows the human capital to be the highest in Prague and Blagoevgrad, where over $40 \%$ of the middle-aged population (25-64) has completed a tertiary level of education. The reason for such a high percentage probably relates to the status of the capital city of Prague and the establishment of the American University in Bulgaria in Blagoevgrad in 1991. Velenje and Székesfehérvár exhibit a higher share of the population with secondary education, while Vaslui exceeds the EU average in the holding percentage of people with primary education.

The economic structure of the wider regions (NUTS 2 level) is closely related to their educational characteristics. The majority of the active population is employed in the service sector $(>55 \%)$. However, Vaslui is an exception with a predominant 
orientation in agriculture, forestry, and fishing (>40\%). Velenje and Székesfehérvár also hold a strong industrial character $(>35 \%)$, while Prague clearly reflects the post-industrial structural settings and orientation in services $(>80 \%)$.

Social exclusion and poverty are more significant for the wider regions (NUTS 2 level) of Vaslui, Blagoevgrad, and Székesfehérvár. The situation is the direst in the Romanian region, where $46 \%$ of people live at the risk of poverty or/and social exclusion. This region is also more problematic than others from the aspect of the participation of young people in education and employment that may escalate social exclusion and poverty in the long-term.

\subsection{Institutional Responses to Civil Initiatives}

Despite the fact that - like in other countries burdened by past totalitarian regimesan action is generally initiated by the municipalities, causing the decision-making process to have remained predominantly top-down, it is important to assess how the administrative personnel in charge of the communication with the citizens perceive, process, and encourage their participation in public affairs. As their aim is to gain knowledge from those who are affected by the issue being addressed and to directly involve citizens in the implementation of the measures, their stance toward more participatory approaches is generally positive. The municipality of Székesfehérvár has in certain cases already recognized the importance of grassroots initiatives, because they often promote and encourage changes, endorsed by the municipality. In Velenje, the main initiator of interventions is the municipality as well, but it was specifically mentioned that NGOs and experts dealing with landscape planning are significant actors in this process. None of the municipalities uses co-governance, in which local communities and the municipality act as equal partners. Székesfehérvár, however, regards two public gardens run by NGOs as examples of co-governance: municipality representatives search for and support grassroots local initiatives managing the gardens, while the NGOs communicate their ideas with the same local representatives at the local electorates or with the employees of the municipal administration.

When citizens do take an initiative and make a proposal to the municipality, municipal administrations have different procedures to respond to it. In Blagoevgrad, the municipality employs personal correspondence and meetings, aided by the NGOs dealing with the issue addressed by the citizens' initiative. In Székesfehérvár, the procedure depends heavily on the topic of the initiative; the respective municipal administrative unit or municipality-owned company from the field of the proposal first decides whether there is a need for their involvement or not. However, the procedure is very bureaucratic and complicated if the citizen who wants to submit a proposal does not have direct contact with an administration employee. In Vaslui, the procedure is highly formalized as well: the citizens' initiative can be brought to the attention of the city administration by a written request. The local authority analyzes the request and if it merits an objective justification, it is debated upon at the local council public meeting and voted for/against. However, the city also provides more 
informal venues for citizen participation: an up-to-date website with all the relevant information on city matters, the green line (TelVerde, a free telephone service to solve issues informally and promptly), face-to-face meetings once a week with the mayor, and an e-mail address where the citizens can pose questions regarding what they are interested in. Similar communication tools are used in Prague 9, where the responses are provided via public and face-to-face meetings, open letters, bulletin boards or noticeboards, web articles, etc. In Velenje, the responses to citizens' initiatives are provided in several ways. People can communicate with the municipality through an e-mail address that involves the mayor, deputy mayor, the mayor's cabinet employees, and all department managers, who then respond to the initiator. The representatives of local communities or councilors can also be reached at the council sessions, which are livestreamed on the municipal website; the conclusions are then distributed via emails. Until 2018, the Urban Points mobile phone application (Urbane točke) allowed direct proposals for improvements by the citizens, which addressed predominantly local issues requiring minor (spatial or any other) interventions; in October 2018, the municipality set up its own internet portal for citizens to submit their initiatives (https://pobude.velenje.si/), which also requires the officials to provide a prompt response.

To sum up, all the municipalities have set up some venues to respond to citizens' initiatives. They do so either through online tools, other communication channels, or personal meetings, but they do not involve the citizens to the point where they could be designated as empowering participation, not to mention co-governance.

\title{
3.5 Tools for Citizen Participation in Strategic and Neighborhood Planning
}

\begin{abstract}
Although citizen participation does not rely solely on the tools for their engagement, they are its precondition. This section thus contains a quantitative overview of the tools used by the municipalities. As already explained, we distinguish between strategic and neighborhood planning, where the first involves designing strategic documents for an entire city/municipality, while the latter applies to a smaller territory. Usually, neighborhood planning gives communities direct power to develop a shared vision for their neighborhood and shape the development and growth of their local area. They are able to choose where they want new homes, shops, and offices to be built, have their say in what those new buildings should look like and what infrastructure should be provided, and grant planning permission for the new buildings they agree with being built. Neighborhood planning provides a set of tools for local people to ensure that they get the right types of development for their community, where the ambition of the neighborhood is aligned with the strategic needs and priorities of the wider local area (Ministry of Housing, Communities \& Local Development 2014).
\end{abstract}


Based on the methodology for the local assessment and analysis of urban green spaces from the Urban Green Belts project (2017), the methods for citizen participation encompass stakeholder platforms (spaces of interaction among different stakeholders who share a common resource and interact to improve mutual understanding, create trust, define roles, and engage in joint action), workshops, living labs (a user-centered, open-innovation ecosystems, often operating in a territorial context—e.g., city, agglomeration, region-, integrating concurrent research and innovation processes within a public-private people partnership), face-to-face meetings, web platforms, social media, consultations and surveys, voting procedures, and awareness-raising campaigns. The municipalities were also called on to list any other tools they have used to achieve citizen participation. They pointed out round tables and public forums, while local media have been generally used to inform people about municipal affairs and to invite them to cooperate with the municipality.

All the selected municipalities except Prague 9 use at least five methods for public participation when designing their strategic documents (see Table 3.3). The nonusage of the tools in Prague 9 stems from the particular authority of Prague's districts, which are in charge only of the matters at the neighborhood (i.e., district) level, while the capital city deals with strategic matters. In Székesfehérvár, however, the methods are used only occasionally and not systematically. Workshops, face-to-face meetings, and web platforms are the most common tools (used in all four municipalities practicing strategic planning), followed by social media and consultation surveys (used in three municipalities). The most varied mix of methods is used in Blagoevgrad, where citizens have several options to get in touch with the municipality: they are involved through eight different tools, including living labs, which are not used in any of the other surveyed municipalities. These mechanisms help the municipalities to initiate a wide discussion of their strategic documents, which outline their visions and priorities, and to receive citizens' proposals on the matters. Some of them then get integrated into the strategies and plans before they are adopted by the municipal council.

The involvement of citizens in neighborhood planning is similar to their involvement at the municipal strategic level (see Table 3.3). The biggest number of involvement tools, seven, is again used in Blagoevgrad. The most commonly used tools are workshops and face-to-face meetings, carried out in all five municipalities. What should be noted is that some municipalities have exercised new ways to use these common tools for citizens' engagement. In Székesfehérvár, the municipality (e.g., the mayor and the local councilor) occasionally organizes public walks through a chosen neighborhood, to which citizens are invited to join and share their opinion (especially concerning development projects), suggest improvements or point out potential problems. The municipalities then take the citizens' ideas gathered through the mentioned tools into account and discuss them at the appropriate councils.

In comparison to the general population, marginalized groups such as the poor, unemployed, homeless, Roma communities, elderly, women, migrants, youth, and other people with special needs are involved in the planning to a lesser extent (see Table 3.4). Their inclusion in strategic planning was reported by Blagoevgrad, Velenje, Székesfehérvár, and Vaslui, while Prague 9 reported their participation solely 


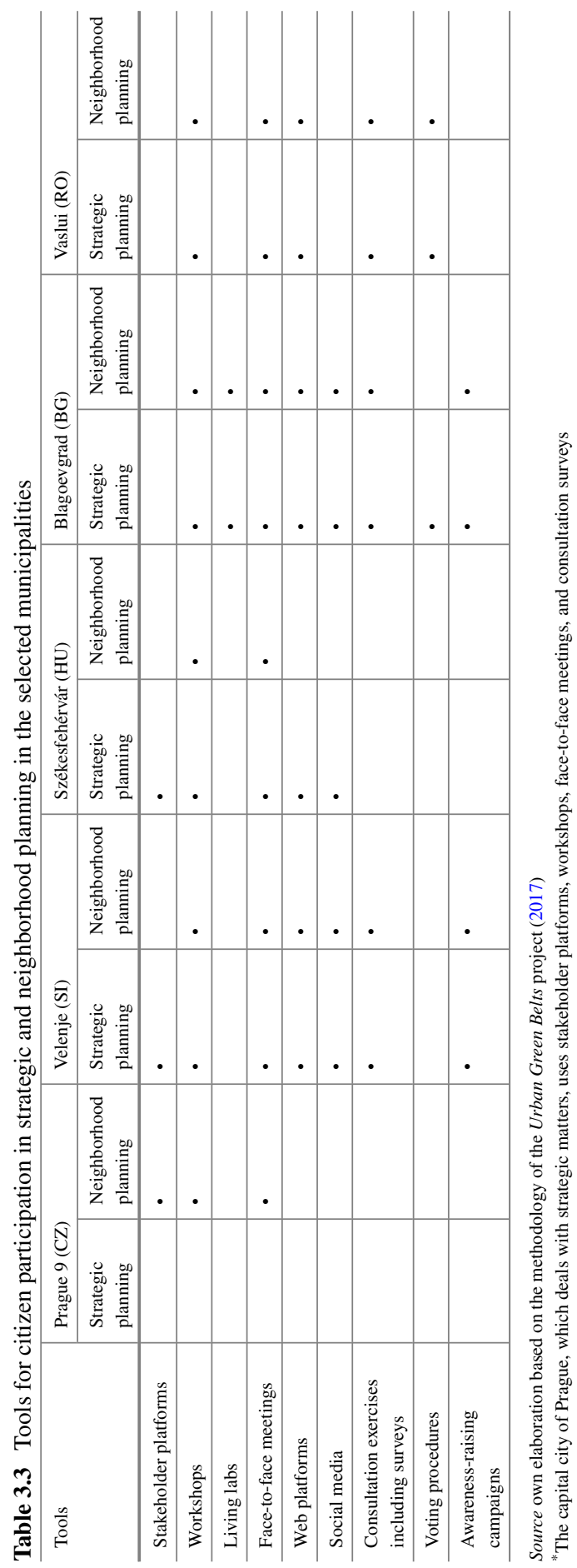




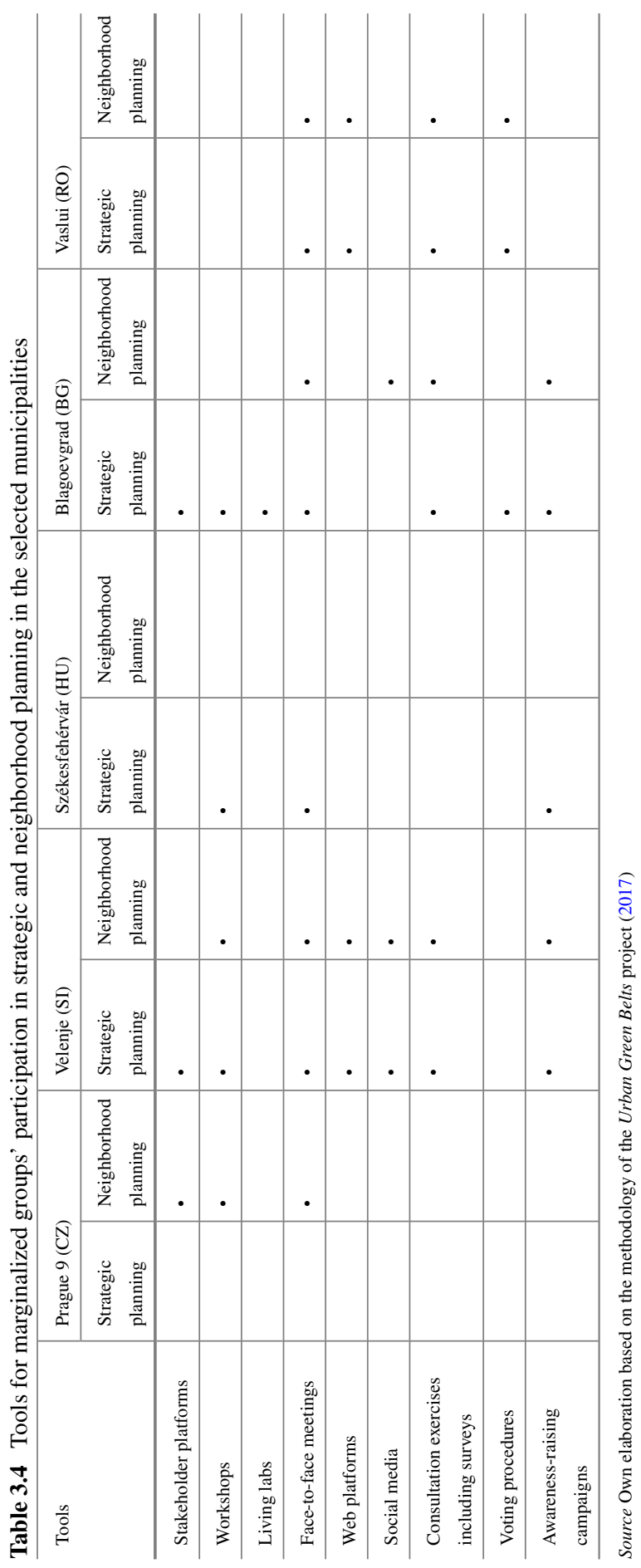


at the neighborhood level (the capital city of Prague deals with strategic planning). However, marginalized groups are targeted (and defined) more specifically only in Blagoevgrad and in certain cases (e.g., youth issues) also in Velenje when applying strategic planning. In Blagoevgrad, a special workshop or living lab is organized for each group, to which its members are usually invited through written invitations put up at public places and in buildings or via social media channels. The municipalities of Blagoevgrad and Velenje also use the biggest variety of tools—seven — for including marginalized groups in strategic planning. In the other municipalities, marginalized groups are not explicitly excluded from participating, but they are also generally not entitled to special treatment and/or attention. As reported by Székesfehérvár, the municipality invites the representatives of NGOs dealing with vulnerable groups to workshops or other events along with the general public.

None of the surveyed municipalities reported a targeted approach for the involvement of marginalized groups at the neighborhood level. The most common tool for their involvement is a face-to-face meeting, which is used in all four municipalities that are applying a participatory approach at that level.

However, the priority of marginalized groups is not political participation, so municipalities make more efforts to improve their social inclusion in everyday life. When asked to specify successful examples of their endeavors, all the municipalities reported various cases of social inclusion. They have used a number of methods, but the prevailing are social help (in all five municipalities), the creation and development of social networks (in four municipalities), and formal or informal meetings (in four municipalities).

\subsection{Experience with Previous Attempts of Participatory Planning}

Four municipalities (except Székesfehérvár, which admits it is in the early stages of incorporating participatory approaches into planning due to the lack of democratic tradition) evaluated their experience with participatory planning. In two cases, they perceived it as positive, meaning that a municipality's aim was fulfilled, i.e., a plan improved, a strategy tested, or a project implemented. In Vaslui, it was found that participation in the development of different plans and strategies added a positive impact on the final proposals, as many inputs were submitted by the citizens. The participatory process was managed mainly by external experts, while the methodology depended on the legal requirements for each strategy or plan. Although participatory approaches are still in the initial phase of implementation, an important step has already been taken: increasing the confidence of the citizens and improving their awareness that their opinion can be an added value to the city's development. The municipality of Blagoevgrad, although admitting a lack of experience with participatory approaches on many levels, also feels that citizen participation has positively contributed to strategic documents, such as the municipal development plan 
for 2014-2020. In such cases, the participation was initiated by the municipality through organizing a public forum where the documents were publicly discussed. Although such approaches have indeed rendered municipal documents or actions a better legitimation, both municipalities pointed out the value of the citizens' tacit knowledge of urban affairs when they initiated participatory planning.

However, not all the experiences have been perceived as positive nor all the practices successful. Sometimes, the process, which is supposed to facilitate an exchange of opinions and ideas, can escalate into unconstructive debates and is (ab)used for personal goals. On other occasions, it can fail to motivate citizens to take a more active role. Two such negatively perceived attempts of participatory planning were reported by Prague 9 and Velenje.

Public administrators from Prague 9 organized participatory sessions of councils or committees when they wanted to get more direct feedback from the citizens regarding specific issues. The citizens were invited "to voice their opinion," however, "no matter what the topic was, they saw [this as] a chance to be heard." On most occasions, the participatory sessions, therefore, turned out to be "only an opportunity for loud and dissatisfied citizens to communicate with the municipal representatives face-to-face," and "the debates quickly escalated into an off-topic mess." According to their explanation, the problem is rooted in the citizens' lack of knowledge about participatory planning and the Czech Republic's excessively bureaucratic system; on the other hand, they also did not seek support by external experts nor tried to acquire the proper qualifications to be able to direct a participatory process in a more constructive manner. Consequently, public administrators from Prague 9 avoided using the participatory approach in planning and have only started to explore and implement it again more systematically in 2017 in the framework of the AgriGo4Cities project.

Velenje reported another less successful example of participatory planning in the field of urban gardening. In 2014, the municipality initiated a setup of urban gardens between the apartment buildings in one of its neighborhoods. They carried out several workshops with residents who responded very positively and were eager to cooperate in the whole process. The municipality even engaged two local landscape architects to assist with their expert knowledge. Unfortunately, the idea stalled just before the pilot action was implemented, i.e., setting up new urban gardens, because the citizens lost interest in having a garden plot, mostly due to its time-consuming management. Despite the action fizzling out in the end, the municipality still evaluates the participatory experience as positive. This experience is in line with admonitions that participatory planning is not a universal solution for all local issues. It does not necessarily render fruitful outcomes, so decision-makers shall judge in which contexts to use it (Hickey and Mohan 2004; Hodgson 2005; Kelty 2017). 


\subsection{Qualification of Public Administrators to Facilitate Participatory Planning}

When citizens contact the municipality to convey an initiative, the municipal administrations make an effort to respond, although in some cases, only if the proposal is evaluated as objectively justified. E-mails and telephone calls, noticeboards, local and social media, online applications, and open office hours of certain departments or public services serve as the main channels to respond. Some procedures are quite formalized, while some municipalities also communicate in a more informal manner. However, qualification training courses for the municipal administration to successfully implement participatory planning have so far been organized only in one surveyed municipality. In Blagoevgrad, the Institute for public administration offers training for state and municipal public officials twice a year. Education is organized into two programs. The first deals with public policies, where participants can learn about the development and application of public policies, acquire skills for joint monitoring and evaluation with NGOs, and learn how to organize public consultations and how to work with stakeholders. The second provides courses on regional and local governing with a focus on strategies and policies for local development and the monitoring of the implementation of local legislative acts. The Blagoevgrad municipal officers have had to successfully pass these courses in order to employ participatory planning in their municipality.

No programs, initiatives, or actions for training the staff or citizens on participatory planning were in progress in other municipalities at the time of the survey, leaving administrative staff having to learn from experience when they are called to instigate a participatory planning process. Furthermore, municipalities rarely employ external experts who would direct participatory actions and contribute to its efficiency and success. Two surveyed municipalities (Vaslui and Velenje) sought help from experts when implementing a participatory planning approach, but it was only done on one occasion in Velenje (when setting up gardens between apartment buildings, see above). In Vaslui, the experts were involved in determining the target group and relevant actors as well as for organizing the workshops. Furthermore, the municipality now implements integrated quality and performance management systems to optimize decision-making and developing the skills of its staff.

It is thus important to work on both sides of the participatory equation not only to increase the capacity of citizens to participate but also for public officials to properly conduct the process. As assessed by Gaventa (2004, p. 27):

The way forward is found in a focus on both a more active and engaged civil society which can express demands of the citizenry, and a more responsive and effective state which can deliver needed public services. 


\subsection{Conclusions}

Participatory governance mechanisms have been widely promoted in the EU (Commission of the European Communities 2001), especially in countries with previously highly centralized (more or less) totalitarian regimes and absent democratic traditions (Petrova 2011). Their introduction is believed not only to motivate active citizenship (also of the marginalized groups, which are generally the most passive in this regard) but also to bring about several public policy benefits, such as increased accountability, higher government responsiveness, and better public services (Speer 2012). However, making participatory governance mechanisms (or arrangements) work has proven to be a great challenge, as was revealed in the survey of five municipalities in Central and Eastern Europe: Municipal district Prague 9 (CZ), Velenje (SI), Székesfehérvár (HU), Blagoevgrad (BG), and Vaslui (RO).

Although the municipalities have different demographic and socio-economic characteristics (size, population, education, economy), the survey revealed that these did not affect participatory planning trajectories, such as the initiation of decisionmaking, participatory methods, experience with participatory planning, and the capacities of public officials to exercise it. Despite the fact that unconventional (bottom-up) political participation (perhaps with the exception of public demonstrations) in post-socialist countries is not as established and popular as in the countries with strong democratic traditions (Hafner Fink 2012), the absence of the correlations between participatory planning and the mentioned characteristics indicates that certain breakthroughs are possible at the local level. However, the decision-making process, as a rule, remains top-down. An action is generally initiated by municipalities with the aim to gain knowledge from those who are affected by the issue or to directly involve them in the implementation of the measures. However, civil society has already been recognized as an important collocutor in municipal planning and municipalities take notice of successful grassroots practices embodying decisions or affairs endorsed by political actors. Despite that positive turn, the question remains on what processes can truly be characterized as participatory governance.

Adopting different tools to allow citizen participation is generally the first (technical) step for their involvement in public policy processes. The methods used in the studied cities are multiple and diverse - although with great potential to increase and diversify-, thus addressing different population groups. The municipalities use at least five tools for strategic planning (except for Prague 9, which transfers strategic planning to the capital city of Prague) and two for planning at the neighborhood level, although not necessarily systematically. Different workshops and face-to-face meetings are the most common participatory methods used in all the surveyed municipalities on both levels. However, the merely occasional use of mechanisms employed in certain cities indicates relatively early stages of participatory governance. A greater number and variety would be the first step to improve the possibility for citizens to participate and to a certain extent limit social exclusion from procedures. However, as shown by some studies in nonwestern countries, mechanisms alone cannot ensure citizen participation (White 1996). The possibility of their engagement can- 
not be taken as a given despite the established tools. Future research shall, therefore, focus less on the methods and more on the question of how municipalities engage to increase their citizens' agency to participate but also when (and if at all) to use the participatory approach for decision-making.

In theory, participatory governance better addresses marginalized groups than representative democracy (McTague and Jakubowski 2013). However, when analyzing the involvement of marginalized groups in decision-making processes in postsocialist urban settings, the picture is not optimistic. Marginalized groups are not explicitly excluded from participating, but they are ordinarily also not entitled to any special treatment, which they generally need to properly respond and cooperate. This results in fewer municipalities actually including marginalized groups in planning and the attempts have been more or less unsystematic. Their inclusion was reported by four municipalities at the strategic (all except Prague 9) and four at the neighborhood level (all but Székesfehérvár), but the targeted approach, which would be crucial for their involvement, was not implemented in any of them at the neighborhood level. However, it was reported by two municipalities (Blagoevgrad and Velenje) when exercising strategic planning, although the latter has only used it once so far, for preparing a strategy on the youth. The most common tool for the involvement of marginalized groups on both levels is a face-to-face meeting. On the other hand, all the municipalities reported a positive experience with social inclusion in everyday life and developed several methods to address marginalized groups. These can increase their motivation for political participation in the long run, as a better (and stable) socio-economic position allows people "to prioritize postmaterialist values over materialist values" (Hafner Fink 2012, p. 561). With the help of NGOs specialized for social work with a certain population, it would be possible to introduce certain approaches to municipal governance as well. Despite the critique (mostly from anthropologists; Riley 2009) that NGOs-instead of municipalities themselves - serve as the purveyors of the participatory approach, they usually ensure more fruitful and sustainable results in cases when the civil society is not well developed, as is often the case in post-socialist countries (Poljak Istenič 2018, 2019).

Although one surveyed municipality (Székesfehérvár) refrained from the evaluation of participatory attempts, as the officials did not think they had the proper experience with such an approach, participatory techniques are generally evaluated as beneficial. Participation in the development of different plans and strategies reportedly adds a positive impact to the final proposals, as they are more attuned with the citizens' observations and needs. The biggest long-term achievements of participatory governance are probably the citizens' increased confidence in their knowledge, a stronger awareness that their opinion counts, and better trust in the authorities.

The results reveal that participatory governance in post-socialist countries (at least the ones surveyed) is still developing and its effective implementation will likely be challenging. However, the problem is not only untrained personnel in public administrations who have difficulty adapting to changed governance models (which is the case in all the municipalities except in Blagoevgrad), but also the citizens who are not used to participate in spatial planning and other governance activities and are not even motivated to participate in traditional forms of political engagement, such 
as elections. It is thus important to work with both citizens and public officials if we want to enforce participatory planning as an efficient governance model. As assessed by Johanna Speer (2012), this also requires increasing the density of civil society and motivating central governments to actively support participatory governance. Instead of the tools for citizen participation, future studies shall therefore focus more on how the municipalities define participatory planning (or governance in general), how they increase the capacities of their staff as well as their citizens (or civil society) for participatory democratic engagement, how they can direct participatory planning, in which occasions they shall use it, and how to actually measure its success: by the number of citizens and/or marginalized groups involved, by the implementation of the planned action, or simply by gaining legitimacy for the municipal measures?

Acknowledgements This chapter was prepared as part of the project AgriGo4Cities (Urban agriculture for changing cities: governance models for better institutional capacities and social inclusion), co-funded by European Union funds (ERDF, IPA), and of two research programs financed by the Slovenian Research Agency: Cultural Spaces and Practices: Ethnology and Folklore Studies (P6-0088) and Geography of Slovenia (P6-0101).

\section{References}

Arnstein SR (1969) A ladder of Citizen participation. J Am Inst Planners 35(4):216-224. https:// doi.org/10.1080/01944366908977225

Bherer L, Dufour P, Montambeault F (2016) The participatory democracy turn: an introduction. J Civil Soc 12(3):225-230. https://doi.org/10.1080/17448689.2016.1216383

Bole D, Šmid Hribar M, Pipan P (2017) Participatory research in community development: a case study of creating cultural tourism products. AUC Geographica 52(2):164-175. https://doi.org/ $10.14712 / 23361980.2017 .13$

Carpentier N (2011) The concept of participation: if they have access and interact, do they really participate? CM-časopis za upravljanje komuniciranjem 6(21):13-36

Chouinard JA, Milley P (2018) Uncovering the mysteries of inclusion: empirical and methodological possibilities in participatory evaluation in an international context. Eval Program Plann 67:70-78. https://doi.org/10.1016/j.evalprogplan.2017.12.001

Commission of the European Communities (2001) European governance: a white paper. European Commission, Brussels

Creative Commons (2012) Participation models: citizens, youth, online. A chase through the maze, 2nd edn. http://www.nonformality.org/wp-content/uploads/2012/11/Participation Models_20121118.pdf. Accessed 8 Jan 2018

Davidson CH, Johnson C, Lizarralde G et al (2007) Truths and myths about community participation in post-disaster housing projects. Habitat Int 31(1):100-115. https://doi.org/10.1016/j.habitatint. 2006.08.003

Fakin Bajec J, Poljak Istenič S (2013) Kako s pomočjo kulturne dediščine doseči trajnostni razvoj podeželja? In: Nared J, Perko D, Razpotnik Visković N (eds) Nove razvojne perspektive. Založba ZRC, Ljubljana, pp 173-180

Finkel SE, Humphries S, Opp KD (2001) Socialist values and the development of democratic support in the former East Germany. Int Polit Sci Rev 22(4):339-361. https://doi.org/10.1177/ 0192512101022004004

Fung A, Wright EO (2001) Deepening democracy: innovations in empowered participatory governance. Polit Soc 29(1):5-41. https://doi.org/10.1177/0032329201029001002 
Gaventa J (2004) Towards participatory governance: assessing the transformative possibilities. In: Hickey S, Mohan G (eds) Participation: from tyranny to transformation. Exploring new approaches to participation in development. Zed Books, London, New York, pp 25-41

Greenberg J (2010) "There's nothing anyone can do about it": participation, apathy, and "successful" democratic transition in Postsocialist Serbia. Slavic Rev 69(1):41-64. https://doi.org/10.1017/ s0037677900016697

Hafner Fink M (2012) Political participation, democratisation and citizens' values in Europe. Teorija in praksa 49(2):544-602

Hayden T (2012) Inspiring participatory democracy: student movements from Port Huron to today. Paradigm Publishers, Boulder

Hickey S, Mohan G (eds) (2004) Participation—from tyranny to transformation? Exploring new approaches to participation in development. Zed Books, London, New York

Hodgson GM (2005) The limits to participatory planning: a reply to Adaman and Devine. Econ Soc 34(1):141-153. https://doi.org/10.1080/0308514042000329360

Hussey S (2017) International public participation models 1969-2016. https://www.bangthetable. com/blog/international-public-participation-models-1969-2016/. Accessed 10 Sept 2018

Kajtazović T (2014) Urbane točke. Mladina 50. https://www.mladina.si/162768/urbane-tocke/. Accessed 10 Sept 2018

Kelty CM (2017) Too much democracy in all the wrong places: toward a grammar of participation. Curr Anthropol 58(suppl 15):77-90. https://doi.org/10.1086/688705

Kozina J, Tiran J, Poljak Istenič S et al (2017) Inventory report on the state of the art of participatory urban agriculture in pilot areas of the Danube Region: final version. Research Centre of the Slovenian Academy of Sciences and Arts, Anton Melik Geographical Institute, Ljubljana. http://www.interreg-danube.eu/uploads/media/approved_project_output/0001/ 14/7c02b7b244ac5956113ccc70837aeb951a5e2a45.pdf. Accessed 10 Sept 2018

Legacy C (2017) Is there a crisis of participatory planning? Plann Theor 16(4):425-442. https:// doi.org/10.1177/1473095216667433

McTague C, Jakubowski S (2013) Marching to the beat of a silent drum: wasted consensus-building and failed neighborhood participatory planning. Appl Geogr 44:182-191

Ministry of Housing, Communities \& Local Development (2014) Neighbourhood planning. Guidance. https://www.gov.uk/guidance/neighbourhood-planning-2\#history. Accessed 15 Sept 2018

Nared J, Razpotnik Visković N, Cremer-Schulte D et al (2015) Achieving sustainable spatial development in the Alps through participatory planning. Acta Geographica Slovenica 55(2):363-373. https://doi.org/10.3986/AGS.1631

Neundorf A (2010) Democracy in transition: a micro perspective on system change in post-socialist societies. J Polit 72(4):1096-1108. https://doi.org/10.1017/s0022381610000551

Pateman C (1970) Participation and democratic theory. Cambridge University Press, Cambridge

Petrova T (2011) Citizen participation in local governance in Eastern Europe: rediscovering a strength of civil society in the post-socialist world? Europe-Asia Stud 63(5):757-787. https:// doi.org/10.1080/09668136.2011.576020

Poljak Istenič S (2018) Green resistance or reproduction of neoliberal politics? Grassroots collaborative practices in Slovenia's “Green Capital” Ljubljana. Ethnologia Europaea 48(1):34-49

Poljak Istenič S (2019) Dwelling participatory style: power and empowerment in a neighborhood renovation and revitalization. J Eur Ethnol Cult Anal (JEECA, Special Issue) 1:90-111

Parvin P (2018) Democracy without participation: a new politics for a disengaged era. Res Publica 24(1):31-52. https://doi.org/10.1007/s11158-017-9382-1

Purcell M (2009) Resisting neoliberalization: communicative planning or counter-hegemonic movements? Plann Theor 8(2):140-165. https://doi.org/10.1177/1473095209102232

Riley KA (2009) Participation and the state: towards an anthropological view of the "new participatory paradigms". New Proposals: J Marxism Interdisc Inquiry 2(2):24-30

Speer J (2012) Participatory governance reform: a good strategy for increasing government responsiveness and improving public services? World Dev 40(12):2379-2398. https://doi.org/10.1016/ j.worlddev.2012.05.034 
Sustainable Measures for Achieving Resilient Transportation in Metropolitan Regions (2016) Inventory on participatory transport planning. https://www.interregeurope.eu/smart-mr/library/ \#folder=185. Accessed 10 Sept 2018

Teorell J, Torcal M, Montero JR (2007) Political participation: mapping the terrain. In: Van Deth JW, Montero JR, Westholm A (eds) Citizenship and involvement in European democracies: a comparative analysis. Routledge, London, New York, pp 334-357

Urban Green Belts (2017) Common methodology for local assessment and analysis of Urban Green Spaces (UGS)

Vlada RS (2018) O projektu. http://www.vlada.si/index.php?id=513. Accessed 10 Sept 2018

White SC (1996) Depoliticising development: the uses and abuses of participation. Dev Pract 6(1):6-15. https://doi.org/10.3362/9780855987015.007

Open Access This chapter is licensed under the terms of the Creative Commons Attribution 4.0 International License (http://creativecommons.org/licenses/by/4.0/), which permits use, sharing, adaptation, distribution and reproduction in any medium or format, as long as you give appropriate credit to the original author(s) and the source, provide a link to the Creative Commons licence and indicate if changes were made.

The images or other third party material in this chapter are included in the chapter's Creative Commons licence, unless indicated otherwise in a credit line to the material. If material is not included in the chapter's Creative Commons licence and your intended use is not permitted by statutory regulation or exceeds the permitted use, you will need to obtain permission directly from the copyright holder.

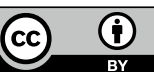

